\begin{tabular}{|c|c|c|}
\hline$C$ & \multicolumn{2}{|c|}{ Case Rep Gastroenterol 2015;9:241-245 } \\
\hline $109 y$ & $\begin{array}{l}\text { DOI: 10.1159/000437293 } \\
\text { Publisnea Onine. July 18, } 2015\end{array}$ & $\begin{array}{l}\text { (C) } 2015 \text { S. Karger AG, Basel } \\
1662-0631 / 15 / 0092-0241 \$ 39.50 / 0 \\
\text { www.karger.com/crg }\end{array}$ \\
\hline & \multicolumn{2}{|c|}{$\begin{array}{l}\text { This is an Open Access article licensed under the terms of the Creative Common } \\
\text { Attribution-NonCommercial } 3.0 \text { Unported license (CC BY-NC) (www.karger.com/OA } \\
\text { license), applicable to the online version of the article only. Distribution permitted for non } \\
\text { commercial purposes only. }\end{array}$} \\
\hline
\end{tabular}

\title{
Mixed Adenoneuroendocrine Carcinoma of the Stomach
}

\author{
Ching-Ming Kwok \\ Division of General Surgery, Department of Surgery, Cheng Hsin General Hospital, Taipei, \\ Taiwan, ROC
}

\section{Key Words}

Adenoneuroendocrine carcinoma · MANECs - Gastric cancer

\begin{abstract}
Mixed adenoneuroendocrine carcinoma is a rare condition comprising at least $30 \%$ of each component of exocrine and endocrine tumors. The denominations were defined in the 2000 WHO classification of endocrine tumors. We report an 83-year-old male with a polypoid gastric tumor in the gastric high body who received total gastrectomy and died 8 months after the diagnosis from local recurrence and distal metastases. A review of the literature for this infrequent condition is presented.

(C) 2015 S. Karger AG, Basel
\end{abstract}

\section{Introduction}

Mixed adenoneuroendocrine carcinoma (MANEC) is a rare condition. Several cases have been reported in the literature with different names, including composite carcinoid, mucinproducing carcinoid, argentaffin cell adenocarcinoma, goblet cell carcinoid, adenocarcinoid, small cell undifferentiated carcinoma, etc. The initial classification of such neoplasms was made by Lewin in 1987 into three different subtypes: collision tumors, combined tumors and amphicrine tumors [1]. In the 2000 WHO classification of endocrine tumors, such neoplasms were defined as mixed exocrine-endocrine tumors when each component represented at least $30 \%$ of the lesion [2]. In the most recent WHO classification of neoplasms of the gastrointestinal tract, such neoplasms are called 'mixed adenoneuroendocrine carcinomas' [3]. This kind of neoplasm usually has a poor prognosis since both components are malignant. There is indeed much variation in the percentage of components between adenocarcinoma and neuroendocrine tumor in gastric cancer. However, those which fit in the criteria of MANEC are infrequent, and only case reports can be found in the literature, thus our 
Kwok: Mixed Adenoneuroendocrine Carcinoma of the Stomach

knowledge is inadequate. The incidence of MANEC has not yet been epidemiologically analyzed since it is one of the rarest types of neuroendocrine tumor. Treatment included surgery or chemotherapy and the diagnosis of the MANECs is based on pathological findings. Here we report a case of this rare condition with a polypoid tumor in the gastric high body who received total gastrectomy; the patient died within 8 months from the disease due to multiple metastases and local recurrence.

\section{Case Report}

An 83-year-old male with a past history of benign prostatic hypertrophy and constipation experienced epigastric pain, dysphagia, belching after meals and a body weight loss of $3 \mathrm{~kg}$ within 1 month (originally $56 \mathrm{~kg}$ ). Upper gastrointestinal panendoscopic examination showed a 3-cm polypoid tumor at the posterior wall of the gastric high body with contact bleeding. Biopsy showed adenocarcinoma with neuroendocrine differentiation and immunoreactivity to CD56. Laboratory data were within normal limits. Computed tomography showed a focal polypoid lesion $(4.5 \times 3.6 \mathrm{~cm})$ in the gastric high body region with adjacent lymph node enlargement (fig. 1), compatible with gastric cancer with lymphadenopathy, cT3N2M0, stage IIIA. The patient received total gastrectomy with Roux-en-Y esophagojejunostomy. Frozen sections for proximal and distal cut ends were tumor-free. A 5-cm well capsulated solid tumor was found in the posterior wall of the high body (fig. 2) and multiple enlarged lymph nodes were noticed in the paragastric region. The tumor infiltrated the serosa of the posterior wall and adhered to the tissues behind the stomach superior to the pancreas tail near the splenic hilum and mesocolon of the transverse colon. Pathology reported a $5 \times$ $4 \times 2.5 \mathrm{~cm}$ polypoid tumor with the diagnosis of MANEC, involving subserosal tissues without invasion of visceral peritoneum, pT3, histological grade 2 adenocarcinoma. One of the group one lymph nodes showed metastasis, pN1. Immunohistochemistry revealed CK (+), chromogranin A (-), synaptophysin (-) and MIB-1 85\% for adenocarcinoma, and CK (+/-), chromogranin A (-), synaptophysin (+) and MIB-1 85\% for neuroendocrine carcinoma (NEC).

The patient recovered slowly, but poor oral intake developed. He did not receive any chemotherapy due to poor nutritional status and general weakness. Anastomosis stricture because of local recurrence occurred 6 months later. Multiple metastases in the liver and pleural effusion were found, and carcinomatosis took place. Supportive care was given and the patient died 8 months after the initial presentation.

\section{Discussion}

There is a wide spectrum of combinations of exocrine and neuroendocrine components in the gastrointestinal tract, ranging from neuroendocrine neoplasms with a focal exocrine component at one extreme to exocrine carcinomas with interspersed neuroendocrine cells at the other. However, mixed exocrine-neuroendocrine tumors are only those neoplasms in which each component represents at least $30 \%$ of the lesion (fig. 3). In addition, both the exocrine and the neuroendocrine components can have different morphological features, ranging from adenomas to adenocarcinomas with different degrees of differentiation in exocrine components and from well differentiated to poorly differentiated neuroendocrine tumors in neuroendocrine components [4, 5]. In the 2010 WHO classification of tumors of the digestive tract, mixed exocrine-neuroendocrine carcinomas are defined as MANECs. They 
Kwok: Mixed Adenoneuroendocrine Carcinoma of the Stomach

are defined as carcinomas since both components are histologically malignant and usually have a poor prognosis.

MANECs can be further divided into high- and low-grade subtypes. High-grade malignant MANEC is a highly malignant composite or combined neoplasm formed by an adenomatous (villous or tubulovillous) or carcinomatous (adenocarcinoma or squamous cell carcinoma) component and by a poorly differentiated (small, intermediate or large cell type) NEC. Equal distribution of the tumor in the upper and lower part of the stomach has been reported [6-8]. Macroscopically, these neoplasms appear as polypoid masses or ulcerating stenotic lesions measuring $0.5-14 \mathrm{~cm}$ in greatest diameter, with a mean size of about $5 \mathrm{~cm}$. Histologically, the NEC component is morphologically similar to small cell or large cell NEC of the lung and corresponds to a grade 3 neuroendocrine neoplasm according to the 2010 WHO classification [3]. A detailed report of the pathological appearance of these categories was published by La Rosa et al. in 2012 [9]. Immunohistochemically, both small and large cell neuroendocrine components are positive for synaptophysin and usually for chromogranin A [10-12]. At least two out of three commonly used neuroendocrine markers (synaptophysin, chromogranin A or CD56) must be abundantly expressed to formulate a diagnosis of high-grade MANEC [3]. The Ki-67 labeling index is usually very high (60-90\%) [13]. Ki-67 and MIB-1 monoclonal antibodies are directed against different epitopes of the same proliferation-related antigen. MIB-1 is used in clinical applications to determine the Ki-67 labeling index. Expression of appropriate or inappropriate hormonal peptides, such as somatostatin, adrenocorticotropic hormone or vasoactive intestinal peptide, have been detected in a few cases of MANEC. Our case was a grade 2 polypoid MANEC with presence of synaptophysin in the neuroendocrine component. Both components of adenocarcinoma and NEC expressed $85 \%$ MIB-1.

A good prognosis of gastric MANEC is rare and usually limited to lesions detected in their early stage [14]. The treatment of choice for gastric MANECs is gastrectomy, either total or subtotal, according to their location, although the optimal treatment strategy is still unknown. In cases with distant metastases, a combination of cisplatin and etoposide had been recommended. Pericleous et al. [15] reported a case of gastric MANEC with trilineage cell differentiation treated palliatively with long-acting somatostatin analogues. However, the optimal treatment policy is still unclear. Our patient did not receive any chemotherapy because of his poor nutritional status and general weakness. Short survival may be a shortcoming of adjuvant therapy.

All MANECs seem to have a poor prognosis, and platinum-based chemotherapy should be the first-line treatment in advanced disease. Gastrectomy must be considered for earlystage lesions or occlusion over the esophagogastric junction and pylorus. Early diagnosis is still the best way to treat the problem.

\section{References}

1 Lewin K: Carcinoid tumors and the mixed (composite) glandular-endocrine cell carcinomas. Am J Surg Pathol 1987;11(suppl 1):71-86.

2 Solcia E, Klöppel G, Sobin LH: Histological Typing of Endocrine Tumours (WHO International Histological Classification of Tumours), ed 2. Berlin, Springer, 2000.

3 Rindi G, Arnold R, Bosman FT, Capella C, Klimstra DS, Kloppel G, Komminoth P, Solcia E: Nomenclature and classification of neuroendocrine neoplasms of the digestive system; in Bosman FT, Carneiro F, Hruban RH, Theise ND (eds): WHO Classification of Tumours of the Digestive System, ed 4. Lyon, IARC Press, 2010, pp 13-14.

4 Capella C, La Rosa S, Uccella S, Billo P, Cornaggia M: Mixed endocrine-exocrine tumors of the gastrointestinal tract. Semin Diagn Pathol 2000;17:91-103. 
Kwok: Mixed Adenoneuroendocrine Carcinoma of the Stomach

5 Volante M, Rindi G, Papotti M: The grey zone between pure (neuro)endocrine and non-(neuro)endocrine tumours: a comment on concepts and classification of mixed exocrine-endocrine neoplasms. Virchows Arch 2006;449:499-506.

6 La Rosa S, Inzani F, Vanoli A, Klersy C, Dainese L, Rindi G, Capella C, Bordi C, Solcia E: Histologic characterization and improved prognostic evaluation of 209 gastric neuroendocrine neoplasms. Hum Pathol 2011;42:1373-1384.

7 Matsui K, Kitagawa M, Miwa A, Kuroda Y, Tsuji M: Small cell carcinoma of the stomach: a clinicopathologic study of 17 cases. Am J Gastroenterol 1991;86:1167-1175.

-8 Rindi G, Bordi C, Rappel S, La Rosa S, Stolte M, Solcia E: Gastric carcinoids and neuroendocrine carcinomas: pathogenesis, pathology, and behavior. World J Surg 1996;20:168-172.

$>9$ La Rosa S, Marando A, Sessa F, Capella C: Mixed adenoneuroendocrine carcinomas (MANECs) of the gastrointestinal tract: an update. Cancers (Basel) 2012;4:11-30.

-10 La Rosa S, Marando A, Furlan D, Sahnane N, Capella C: Colorectal poorly differentiated neuroendocrine carcinomas and mixed adenoneuroendocrine carcinomas: insights into the diagnostic immunophenotype, assessment of methylation profile, and search for prognostic markers. Am J Surg Pathol 2012;36:601-611.

-11 Bernick PE, Klimstra DS, Shia J, Minsky B, Saltz L, Shi W, Thaler H, Guillem J, Paty P, Cohen AM, Wong WD: Neuroendocrine carcinomas of the colon and rectum. Dis Colon Rectum 2004;47:163-169.

-12 Klimstra DS, Modlin IR, Adsay NV, Chetty R, Deshpande V, Gönen M, Jensen RT, Kidd M, Kulke MH, Lloyd RV, Moran C, Moss SF, Oberg K, O'Toole D, Rindi G, Robert ME, Suster S, Tang LH, Tzen CY, Washington MK, Wiedenmann B, Yao J: Pathology reporting of neuroendocrine tumors: application of the Delphic consensus process to the development of a minimum pathology data set. Am J Surg Pathol 2010;34:300-313.

13 Tanabe T, Nishimaki T, Kanda T, Nakagawa S, Ohashi M, Hatakeyama K: Esophageal composite carcinoma with tripartite differentiation: clinicopathological analysis of three cases. Esophagus 2005;2:91-96.

14 Fukuba N, Yuki T, Ishihara S, Sonoyama H, Tada Y, Kusunoki R, Oka A, Oshima N, Moriyama I, Kawashima K, Kinoshita Y: Gastric mixed adenoneuroendocrine carcinoma with a good prognosis. Intern Med 2014;53: 2585-2588.

15 Pericleous M, Toumpanakis C, Lumgair H, Caplin ME, Morgan-Rowe L, Clark I, Luong TV: Gastric mixed adenoneuroendocrine carcinoma with a trilineage cell differentiation: case report and review of the literature. Case Rep Oncol 2012;5:313-319.

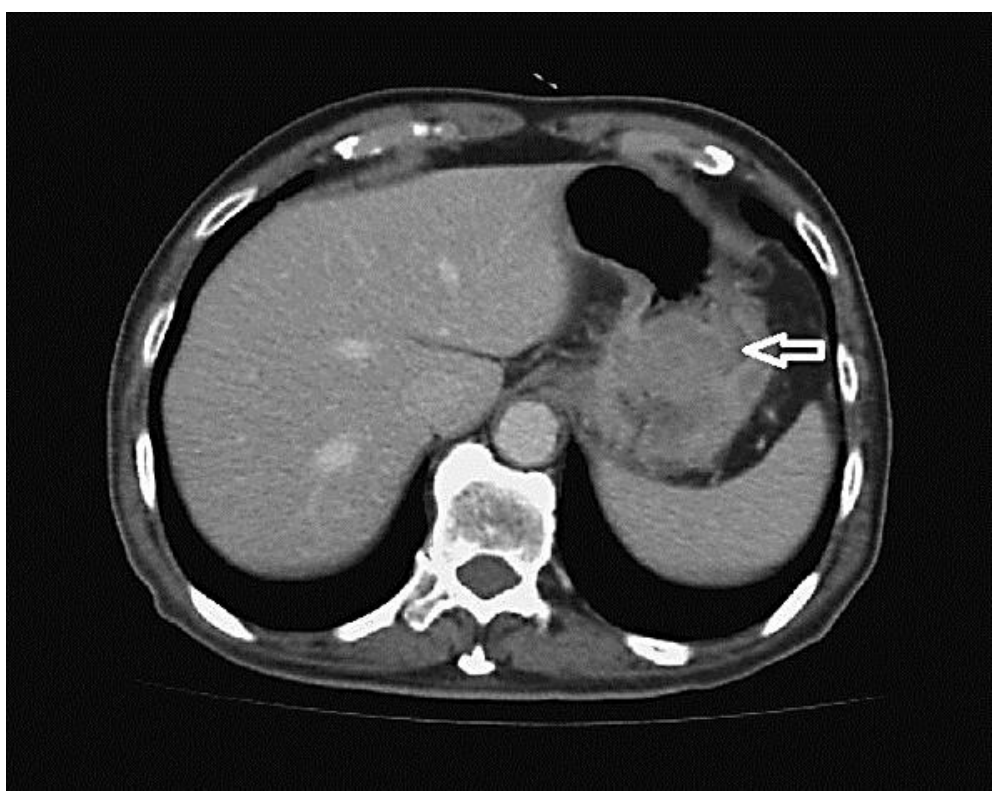

Fig. 1. Computed tomography showed a focal polypoid lesion $(4.5 \times 3.6 \mathrm{~cm})$ in the gastric high body region protruding into the lumen nearby the esophagogastric junction (arrow) with adjacent lymph node enlargement. 


\begin{tabular}{|c|c|c|}
\hline \multirow{2}{*}{$\begin{array}{l}\text { Case Reports in } \\
\text { Gastroenterology }\end{array}$} & \multicolumn{2}{|c|}{ Case Rep Gastroenterol 2015;9:241-245 } \\
\hline & DOI: $10.1159 / 000437293$ & $\begin{array}{l}\text { (c) } 2015 \text { S. Karger AG, Base } \\
\text { www.karger.com/crg }\end{array}$ \\
\hline
\end{tabular}

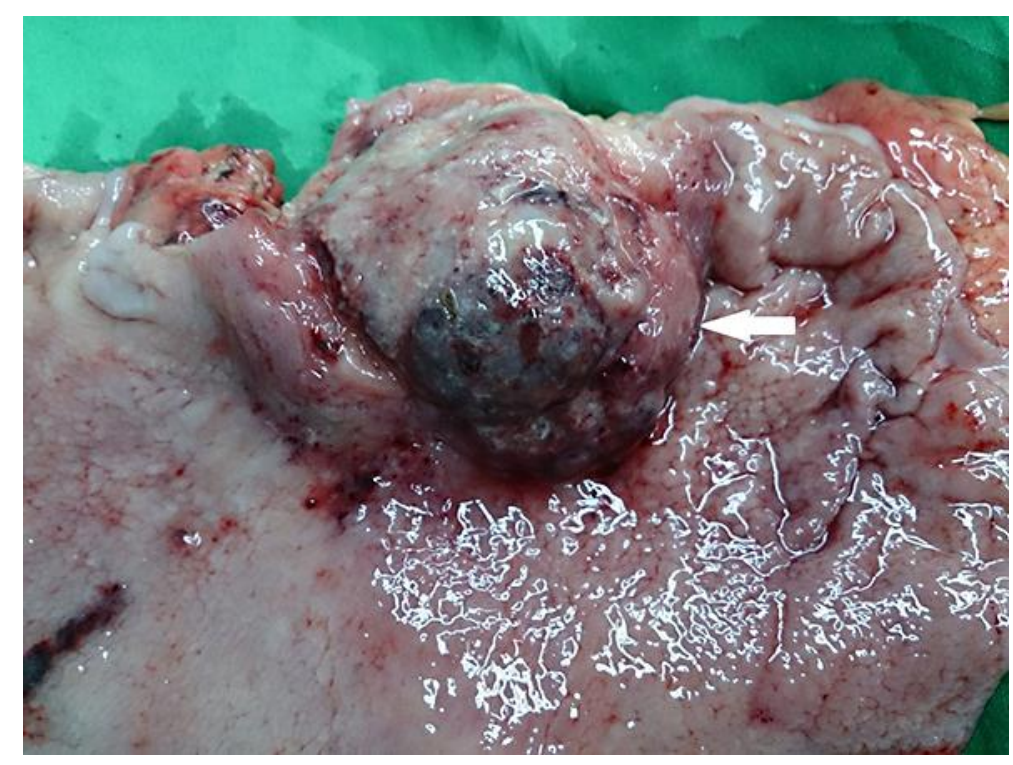

Fig. 2. A 5-cm tumor in the posterior wall of the high body (arrow). The tumor protruded into the stomach lumen with wall thickening of the gastric wall, located near the esophagogastric junction.

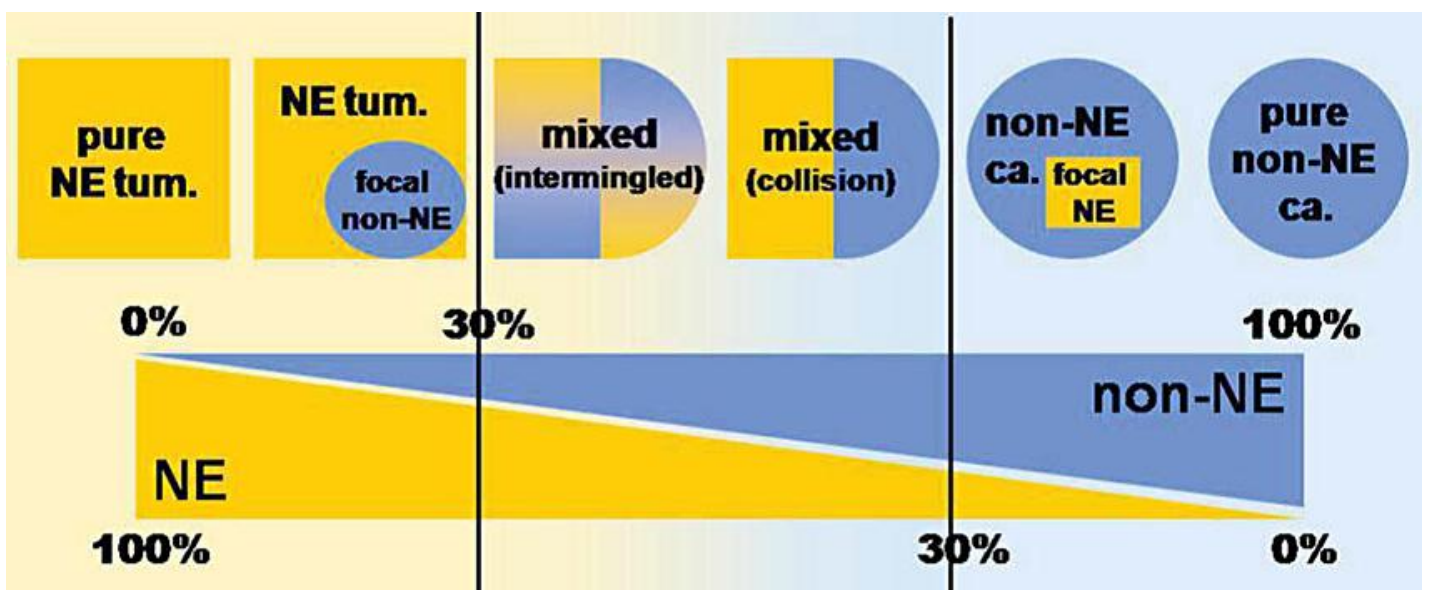

Fig. 3. Schematic representation showing the wide spectrum of combinations of exocrine and neuroendocrine components in human tumors, ranging from neuroendocrine neoplasms with a focal exocrine component at one extreme (left) to exocrine carcinomas with interspersed neuroendocrine cells at the other (right). However, mixed exocrine-neuroendocrine tumors (middle) are only those neoplasms in which each component represents at least $30 \%$ of the lesion. $\mathrm{NE}=$ Neuroendocrine; tum. $=$ tumor; ca. $=$ carcinoma. Modified from Volante et al. [5]. 